Article

\title{
Eliminating Aluminum Toxicity in an Acid Sulfate Soil for Rice Cultivation Using Plant Growth Promoting Bacteria
}

\section{Qurban Ali Panhwar 1,2, Umme Aminun Naher ${ }^{3,4}$, Othman Radziah ${ }^{1,3}$, Jusop Shamshuddin 1,3,* and Ismail Mohd Razi ${ }^{3}$}

1 Department of Land Management, Faculty of Agriculture, Universiti Putra Malaysia, UPM Serdang, Selangor 43400, Malaysia

2 Soil Chemistry Section, Agricultural Research Institute, Tandojam 70060, Sindh, Pakistan

3 Institute of Tropical Agriculture, Universiti Putra Malaysia, UPM Serdang, Selangor 43400, Malaysia

4 Bangladesh Rice Research Institute, Gazipur 1701, Bangladesh

* Author to whom correspondence should be addressed; E-Mail: shamshud@upm.edu.my; Tel.: +60-38-947-4865

Academic Editor: Derek J. McPhee

Received: 3 November 2014 / Accepted: 4 January 2015 / Published: 20 February 2015

\begin{abstract}
Aluminum toxicity is widely considered as the most important limiting factor for plants growing in acid sulfate soils. A study was conducted in laboratory and in field to ameliorate Al toxicity using plant growth promoting bacteria (PGPB), ground magnesium limestone (GML) and ground basalt. Five-day-old rice seedlings were inoculated by Bacillus sp., Stenotrophomonas maltophila, Burkholderia thailandensis and Burkholderia seminalis and grown for 21 days in Hoagland solution ( $\mathrm{pH} 4.0)$ at various $\mathrm{Al}$ concentrations $(0,50$ and $100 \mu \mathrm{M})$. Toxicity symptoms in root and leaf were studied using scanning electron microscope. In the field, biofertilizer (PGPB), GML and basalt were applied ( $4 \mathrm{t} \cdot \mathrm{ha}^{-1}$ each). Results showed that $\mathrm{Al}$ severely affected the growth of rice. At high concentrations, the root surface was ruptured, leading to cell collapse; however, no damages were observed in the PGPB inoculated seedlings. After 21 days of inoculation, solution $\mathrm{pH}$ increased to $>6.0$, while the control treatment remained same. Field study showed that the highest rice growth and yield were obtained in the bio-fertilizer and GML treatments. This study showed that $\mathrm{Al}$ toxicity was reduced by PGPB via production of organic acids that were able to chelate the $\mathrm{Al}$ and the production of polysaccharides that increased solution $\mathrm{pH}$. The release of phytohormones further enhanced rice growth that resulted in yield increase.
\end{abstract}


Keywords: Al speciation; chelation; indoleacetic acid; phytohormone; ameliorative effect

\section{Introduction}

Al toxicity is the main reason causing stunted root growth. In acidic soils, $\mathrm{Al}^{3+}$ limits the growth of roots either by inhibition of cell division, cell elongation or by both [1]. In rice and other cereals, this problem can cause about $30 \%-40 \%$ of crop yield reduction. Aluminum toxicity can be reduced by neutralizing the acidity using calcareous amendments [2]. Many plants have different mechanisms to tolerate the noxious effect of $\mathrm{Al}$ in response to this stress. These resistance mechanisms in plants have been categorized as: (a) external via the exudation of organic acids from the radical apexes and subsequent chelation of the Al in the rhizosphere; and (b) internal or Al-tolerant as Al chelation is produced inside the cell and then later stored and compartmentalized in cell organelles like the vacuole [3].

A small number of plant species have the ability to detoxify Al in the rhizosphere by exuding organic acids from their roots [4]. The exudation is situated in the radical apexes, as this is a place which is very susceptible to Al toxicity [5]. Organic acids play a vital role in external and internal neutralization of Al. Generally, organic acids secreted by plant roots are malate, citrate and oxalate. Malate and citrate are present in all cells which are required for the mitochondrial respiratory cycle [6]. The amount of organic acids released varies between plant species, and the detoxification mechanism is an internal tolerance [7-9]. Among the organic acids, malate is the one that reveals the least capacity to chelate $\mathrm{Al}$ ions [10].

It is proven that higher number of PGPR/PGPB is associated with rice rhizosphere [11] and they have the potential to produce a large amount of organic acids [12], which resulted in P binding by chelation, and may also be a possible mechanism for reducing Al toxicity of roots. The better performance of the PGPR/PGPB for the plant growth promotion occurs with the mixture of strains rather than individual strains [13]. In addition, the application of these beneficial microorganisms enhances the economic efficiency in terms of reduced production cost of phosphorus fertilizers [14]. Addition of these potential PGPR would enhance the growth of rice grown on soils with high Al content.

Low $\mathrm{pH}$ soils, especially acid sulfate soils, contain low total microorganisms, with their amount varying considerably according to vegetation type and soil management practices. Due to food security, attention is now focusing on rice production in less fertile acidic soils which are usually subjected to $\mathrm{Al}$ toxicity. Hence, the present study was undertaken: (1) to determine methods of increasing rice production in high Al containing soils using environmentally-friendly PGPB and/or soil amendments; and (2) to explain the possible mechanisms involved in this process.

\section{Results and Discussion}

\subsection{Laboratory Study}

Various PGPB have been used in this study. These PGPB have the ability to fix nitrogen (Stenotrophomonas maltophilla Sb16), can solubilize phosphate and produce organic acids: (Bacillus sp. PSB16, Burkholderia thailandensisASB7, and Burkholderia seminalis ASB21) (Table 1). All the bacteria were able to produce indoleacetic acid and exopolysaccharides in culture solution (Figure 1). 
Table 1. Bio-chemical properties of the bacterial strains.

\begin{tabular}{|c|c|c|c|c|c|c|c|}
\hline \multirow[t]{2}{*}{ Strains } & \multirow{2}{*}{$\begin{array}{c}\text { IAA } \\
\left(\mathbf{m g} \cdot \mathbf{L}^{-1}\right)\end{array}$} & \multicolumn{4}{|c|}{$\begin{array}{l}\text { Production of Organic Acid } \\
\left(\mathrm{mg} \cdot \mathrm{L}^{-1}\right)\end{array}$} & \multirow[t]{2}{*}{ BNF } & \multirow{2}{*}{$\begin{array}{l}\text { P solubilization } \\
\text { from PR }\end{array}$} \\
\hline & & $\mathbf{O A}$ & MA & SA & PA & & \\
\hline Bacillus sp. (PSB16) & 6.78 & 0.03 & 0.07 & 0.24 & 0.006 & $+\mathrm{ve}$ & From soil $* 86 \%$ \\
\hline $\begin{array}{l}\text { Stenotrophomonasmaltophila } \\
\text { (Sb16) }\end{array}$ & 55.00 & 0.06 & 0.04 & 0.39 & 0.008 & ** $62 \mathrm{~kg} \cdot \mathrm{ha}^{-1}$ & - \\
\hline $\begin{array}{l}\text { Burkholderiathailandensis } \\
\text { (ASB7) }\end{array}$ & 13.16 & 0.02 & 0.05 & 0.24 & 0.012 & $+\mathrm{ve}$ & $\begin{array}{l}\text { From broth culture } \\
\text { (72 h) } 3.4 \%\end{array}$ \\
\hline $\begin{array}{l}\text { Burkholderiaseminalis } \\
\text { (ASB21) }\end{array}$ & 12.16 & 0.09 & 0.08 & 0.42 & 0.018 & $+\mathrm{ve}$ & $\begin{array}{l}\text { From broth culture } \\
\text { (72 h) } 2.72 \%\end{array}$ \\
\hline
\end{tabular}

Notes: IAA: Indoleacetic acid; OA: oxalic acid; MA: malic acid; SA: Salicylic acid; PA: propionic acid; BNF: biological nitrogen fixation; PR: phosphate rock. ${ }^{*}$ determined using ${ }^{32} \mathrm{P}$ isotope technique; ${ }^{* *}$ determined using ${ }^{15} \mathrm{~N}$ isotope technique.

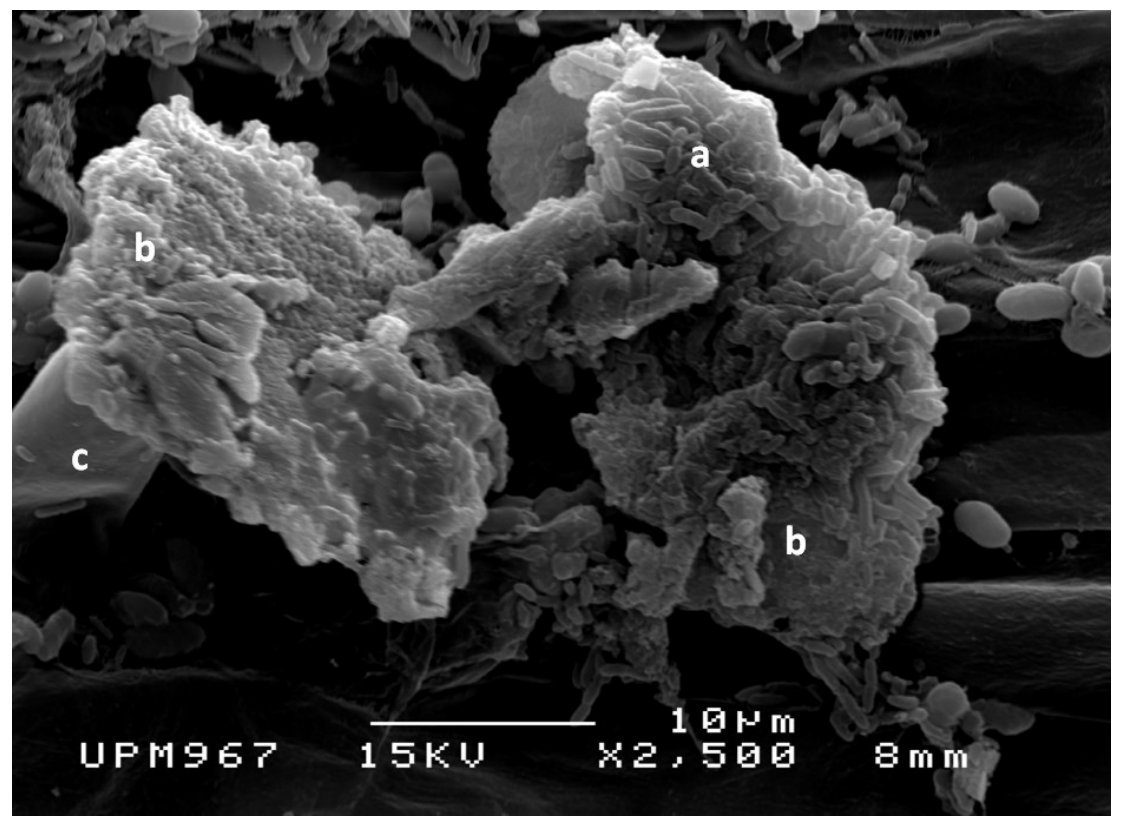

Figure 1. Exopolysaccharides production by the bacteria (a); showing gummy material (b) and covering root hair $(\mathbf{c})$.

\subsubsection{Effect of Al on the Growth of Rice Seedlings Inoculated with PGPB}

It was observed that high Al concentration had severely affected the growth of the rice seedlings. Plant height, dry biomass and root volume were significantly decreased with the increased Al concentrations (Figure $2 \mathrm{a}-\mathrm{c}$ ). In contrast, the bacterial inoculated plants were less affected by the high Al concentration. The lowest plant height and dry biomass was found in the non-inoculated plants at $100 \mu \mathrm{M} \mathrm{Al}$ concentration. However, higher plant height $(18.8$ and $18 \mathrm{~cm})$ and the highest plant dry biomass $(0.76$ and $0.75 \mathrm{~g})$ were recorded due to Sb16 and ASB7 inoculation in the absence of Al. In this study, it was observed that root architecture and root volume varied with $\mathrm{Al}$ concentrations and bacterial inoculation. The presence of $\mathrm{Al}$ had affected roots and the detrimental effects were more profound at higher concentrations (Figure 2c). Generally, higher root volume was found in the inoculated compared to the non-inoculated 
rice plants. In the absence of $\mathrm{Al}$, the highest root volume was obtained in the rice plant inoculated with Sb16 $\left(7.3 \mathrm{~cm}^{3}\right)$, followed by ASB21 $\left(6.9 \mathrm{~cm}^{3}\right)$ and PSB16 $\left(6.88 \mathrm{~cm}^{3}\right)$. The lowest root volume $\left(1.03 \mathrm{~cm}^{3}\right)$ was found in the control non-inoculated plants at $100 \mu \mathrm{M}$ Al concentration. At the highest level of Al, higher root volume was observed in the inoculated rice plants compared to that of the control treatment.

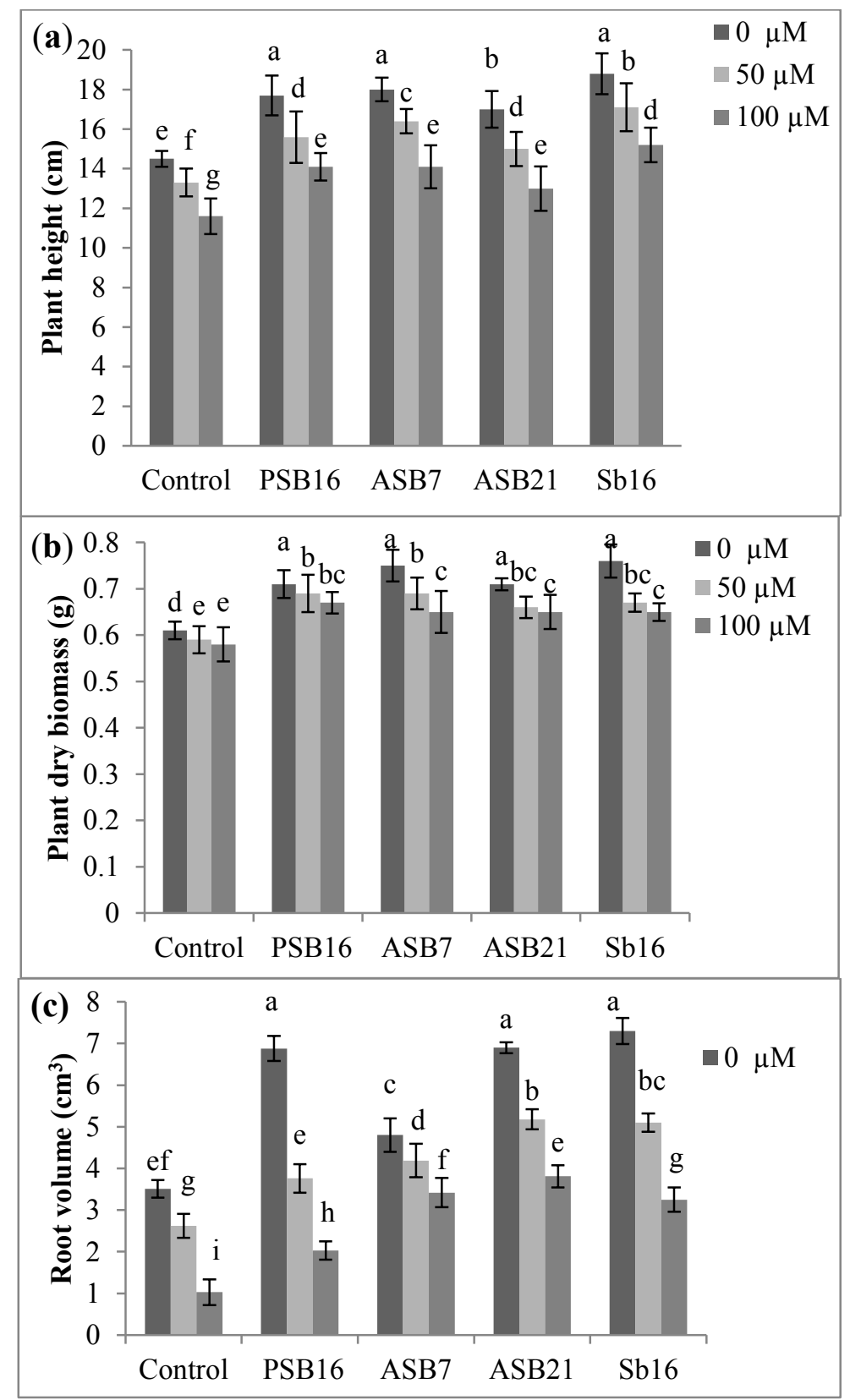

Figure 2. Effects of $\mathrm{Al}$ on the growth of rice seedlings inoculated with PGPB: (a) plant height; (b) plant dry biomass; and (c) root volume. Where, PSB $16=$ Bacillus sp., Sb16 = Stenotrophomonas maltophila, ASB7 = Burkholderia thailandensis, ASB21 = Burkholderia seminalis. Means within the same column followed by the same letters are not significantly different at $p<0.05$. Bars indicate standard error, $n=4$. 


\subsubsection{Effects of $\mathrm{Al}$ on the Population of PGPB}

It was found that the population of PGPB was affected by the presence of Al. High Al concentration seemed to be slightly affected the PGPB population, shown by the higher population at $0 \mu \mathrm{M} \mathrm{Al}$ concentration compared to that of the others (Table 2). With the increase in Al concentration, the PGPB population decreased, and this trend was observed for all the PGPB strains. As the experiment was conducted in controlled conditions, there was no bacterial population recorded. However, there was a clear indication that bacterial strains still existed under the stress of low $\mathrm{pH}$ and high $\mathrm{Al}$ concentrations. Hence, these PGPB have the potential to be used in bio-fertilizer formulation for rice cultivation in acid sulfate soils.

Table 2. Effects of $\mathrm{Al}$ on the bacterial population and on $\mathrm{pH}$ of the growth medium.

\begin{tabular}{cccccccc}
\hline \multirow{2}{*}{ Treatments } & \multicolumn{3}{c}{$\begin{array}{c}\text { Bacterial Population } \\
\left(\log _{10} \mathbf{C F U} \cdot \mathbf{m L}^{-1}\right)\end{array}$} & \multicolumn{3}{c}{ pH Values * } \\
\cline { 2 - 7 } & $\mathbf{0}$ & $\mathbf{5 0}$ & $\mathbf{1 0 0}$ & $\mathbf{0}$ & $\mathbf{5 0}$ & $\mathbf{1 0 0}$ \\
\cline { 2 - 7 } & \multicolumn{4}{c}{$\mathbf{A l}(\boldsymbol{\mu M})$} \\
Control & - & - & - & $3.95 \mathrm{c}$ & $3.25 \mathrm{~b}$ & $2.93 \mathrm{c}$ \\
Bacillus sp. (PSB16) & $10.83 \mathrm{~b}$ & $9.23 \mathrm{~b}$ & $8.23 \mathrm{~b}$ & $7.12 \mathrm{a}$ & $6.85 \mathrm{a}$ & $6.50 \mathrm{a}$ \\
Burkholderia thailandensis (ASB7) & $10.79 \mathrm{~b}$ & $9.68 \mathrm{a}$ & $7.69 \mathrm{c}$ & $6.85 \mathrm{~b}$ & $6.72 \mathrm{a}$ & $6.64 \mathrm{a}$ \\
Burkholderia seminalis (ASB21) & $10.87 \mathrm{~b}$ & $9.57 \mathrm{a}$ & $8.11 \mathrm{~b}$ & $6.87 \mathrm{~b}$ & $6.65 \mathrm{a}$ & $6.00 \mathrm{~b}$ \\
Stenotrophomonas maltophila (Sb16) & $11.07 \mathrm{a}$ & $9.61 \mathrm{a}$ & $8.54 \mathrm{a}$ & $7.09 \mathrm{a}$ & $6.71 \mathrm{a}$ & $6.30 \mathrm{a}$ \\
\hline
\end{tabular}

Note: * The initial pH was fixed at 4.0. Means within the same column followed by the same letters are not significantly different at $p<0.05$.

\subsubsection{Effects of PGPB on $\mathrm{pH}$ of the Growth Medium}

It was observed that the $\mathrm{pH}$ of control treatment remained almost the same. On the other hand, in PGPB inoculated treatments, the $\mathrm{pH}$ was increased up to more than 6.0 (Table 2). It means that the increase in $\mathrm{pH}$ by the action of the PGPB would have profound ameliorative effects on rice productivity either in growing medium or in the field.

\subsubsection{Effects of Al on the Release of Organic Acids}

It was observed that organic acids released by the rice roots with or without PGPB varied with $\mathrm{Al}$ concentrations (Figure $3 \mathrm{a}-\mathrm{c}$ ). Rice root without PGPB inoculation secreted a lower amount of organic acids compared to those inoculated with the bacteria. The release of organic acids was enhanced by PGPB inoculation at high concentrations of Al. Higher amounts of malic and citric acids were released by the bacteria compared to oxalic acid. The amount of malic acid was found to be high, particularly at $100 \mu \mathrm{M} \mathrm{Al}$ concentration. 


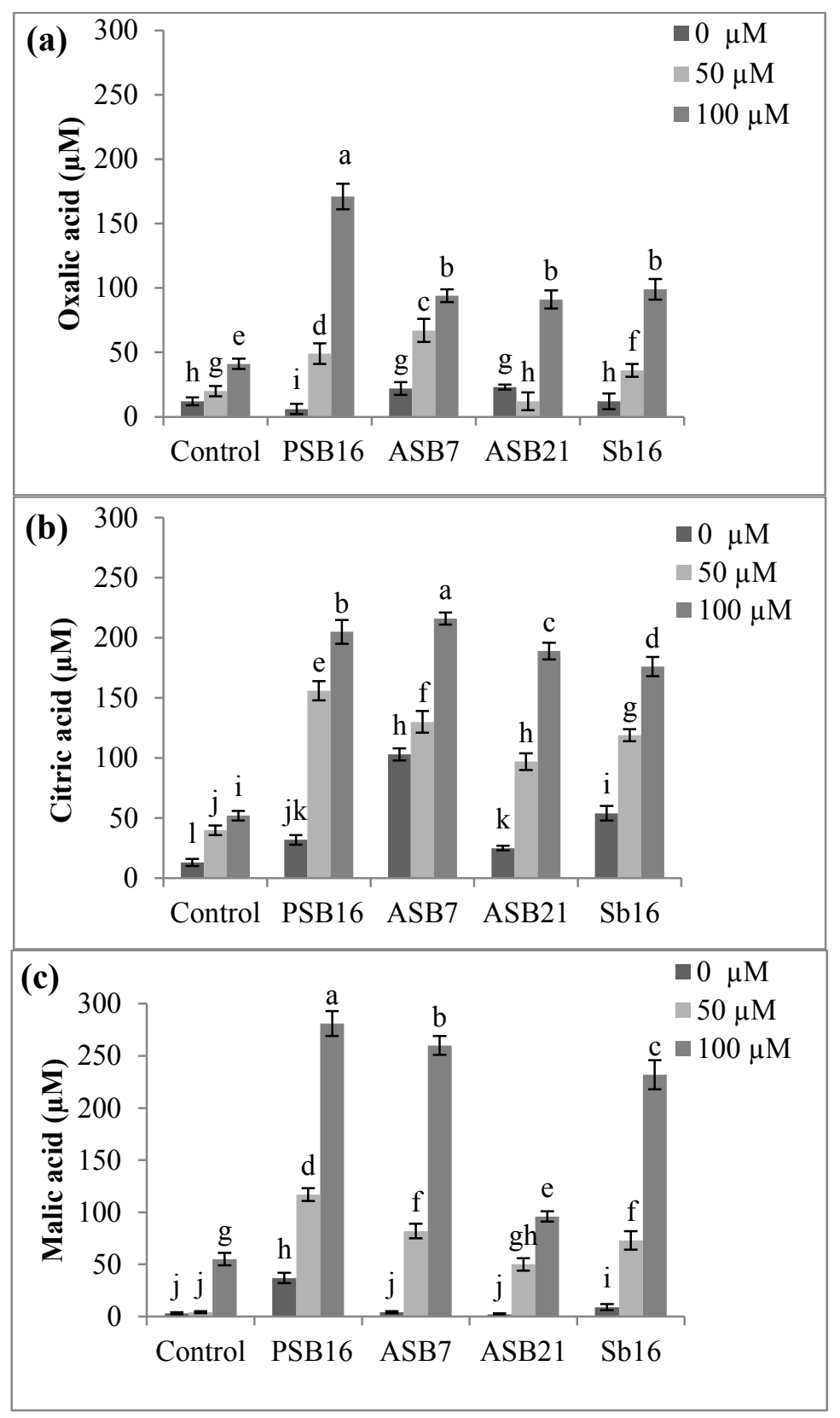

Figure 3. Effects of $\mathrm{Al}$ on the release of organic acids by rice plant and or PGPB: (a) oxalic; (b) citric; and (c) malic acid. Where, PSB 16 = Bacillus sp., Sb16 = Stenotrophomonas maltophila, ASB7 = Burkholderia thailandensis, ASB21 = Burkholderia seminalis. Means within the same column followed by the same letters are not significantly different at $p<0.05$. Bars indicate standard error, $n=4$.

\subsubsection{Effect of $\mathrm{Al}$ on the Rice Roots and Leaf Cells}

Effects of $\mathrm{Al}$ on the morphology of rice root cell was visually observed under SEM. High Al concentration $(100 \mu \mathrm{M})$ affected the root cortical tissues, causing rapture at the root surface, and root cells collapsed in the un-inoculated treatment (Figure 4c,e). The inoculated rice plants still contained bacteria even at $100 \mu \mathrm{M} \mathrm{Al}$ concentration without showing any surface rapture or root cell collapse (Figure 4b,d,f). Cells damage in the root cortex of rice plants without PGPB inoculation was clear evidence of the effects of Al toxicity. 

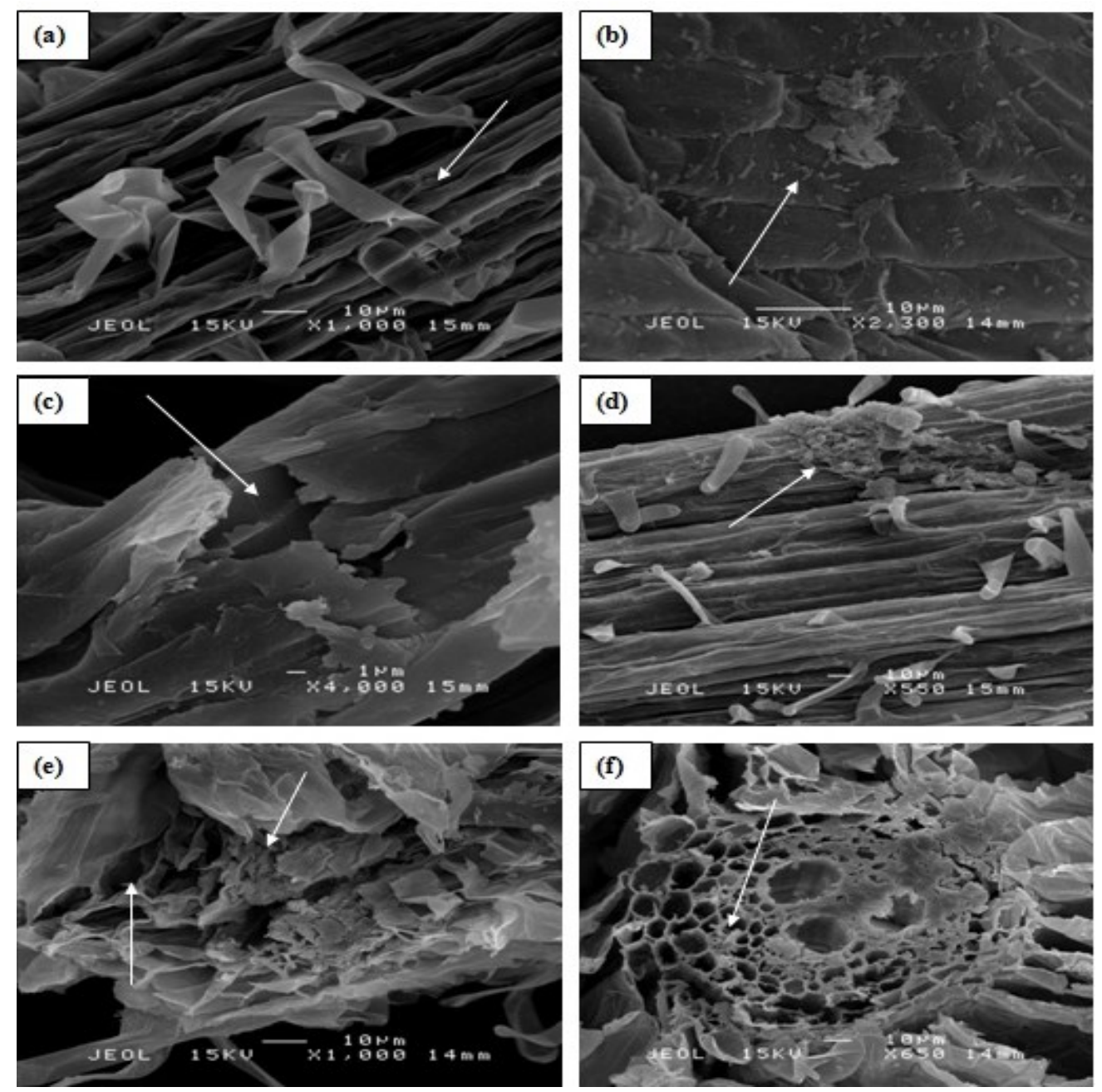

Figure 4. Scanning electron micrographs showing the effects of Al toxicity in rice roots: (a) root surface in the control treatment at $0 \mu \mathrm{M} \mathrm{Al}$, arrow shows no rupturing and microbes presence (b) PGPB inoculated root surface at $0 \mu \mathrm{M} \mathrm{Al}$, arrow shows the microbes on the root surface (c) showing root cracks and tearing of the cells in the rhizodermis and outer cortex resulting in the formation of transverse ruptures in the control treatment at $100 \mu \mathrm{M}$ $\mathrm{Al}$, (d) showing PGPB inoculated root surface at $100 \mu \mathrm{M} \mathrm{Al}$, arrow shows the microbes on the root surface (e) showing the effects on the root cortical tissues in the control treatment at $100 \mu \mathrm{M} \mathrm{Al}$, arrows indicate the distance of a rupture at the interior- and exterior-surface of an individual cell and (f) showing root cortical tissues inoculated with PGPB at $100 \mu \mathrm{M}$ Al concentration, arrow indicates microbes in the root cortical tissues.

From the scanning electron microscopic study, it was revealed that at $0 \mu \mathrm{M} \mathrm{Al}$ concentration there were no glands present in the leaf (Figure 5a,b). However, rupture on the rice leaf surface (Figure 5b) and internal leaf cells destruction in the control treatment appeared at $100 \mu \mathrm{M} \mathrm{Al}$ concentration (Figure 5e). The leaf surface damages were observed longitudinally arranged in parallel rows, adjacent to the rows of stomata. There was severe cell rupture occurring at the $100 \mu \mathrm{M} \mathrm{Al}$ concentration (Figure 5e). However, there were no damages (Figure 5d) and cell rapture observed (Figure 5f) in the rice plants inoculated with PGPB even at the highest Al concentration of $100 \mu \mathrm{M}$. 

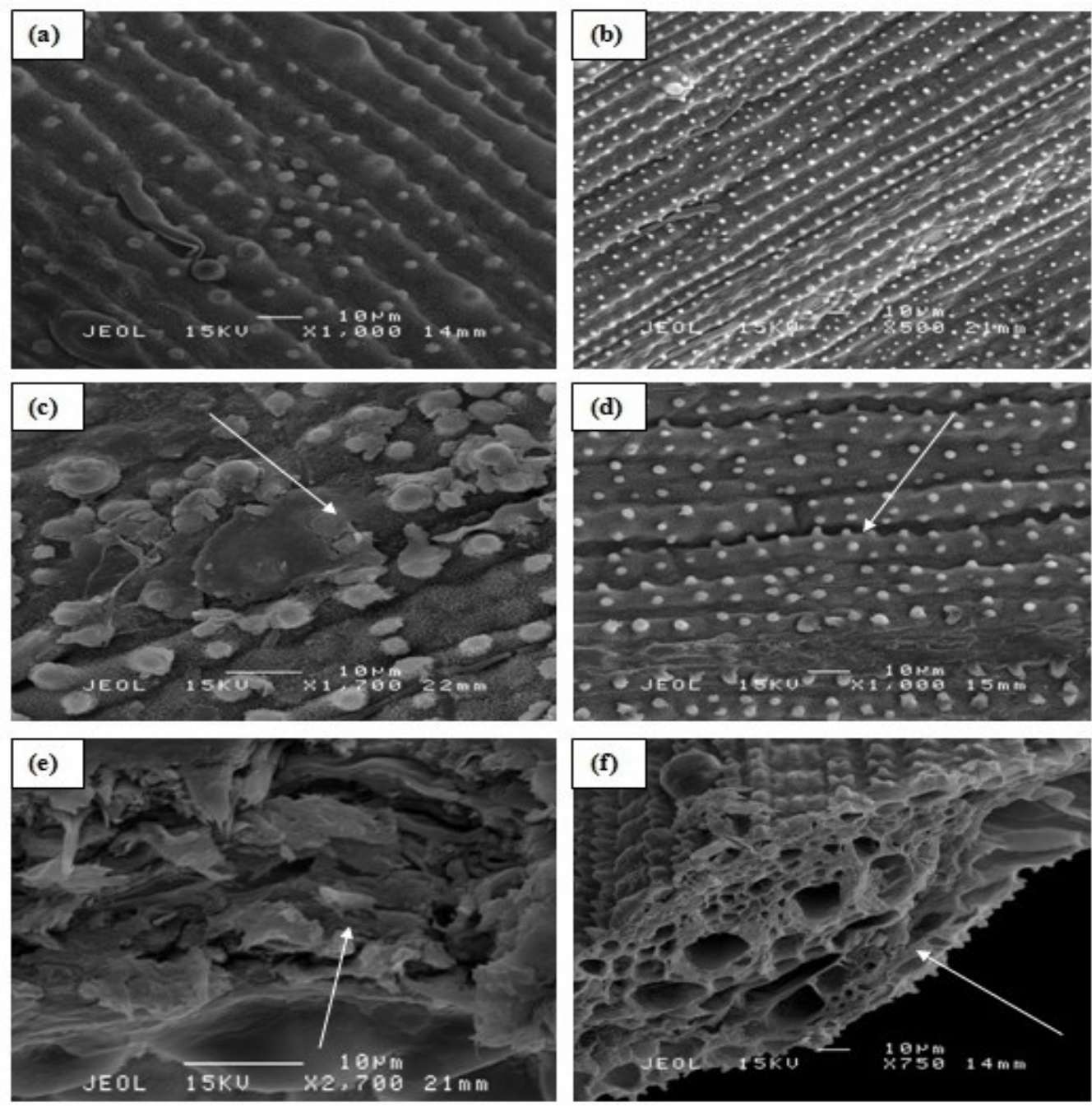

Figure 5. Scanning electron micrographs showing adaxial rice leaf surface and leaf cells: (a) showing leaf surface in the control treatment at $0 \mu \mathrm{M} \mathrm{Al}$; (b) showing adaxial leaf surface inoculated with PGPB at $0 \mu \mathrm{M} \mathrm{Al}$; (c) showing ruptured leaf surface in the control treatment at $100 \mu \mathrm{M} \mathrm{Al}$; (d) showing PGPB inoculated leaf surface at $100 \mu \mathrm{M} \mathrm{Al}$, without any rupturing; (e) showing internal destructive leaf cells in the control treatment at $100 \mu \mathrm{M} \mathrm{Al}$; and (f) showing internal healthy leaf cells at $100 \mu \mathrm{M}$ Al concentration (PGPB inoculated), arrow shows the normal leaf cells.

\subsection{Field Study}

2.2.1. Effects of Biofertilizer, Basalt and Ground Magnesium Limestone (GML) Applications on the Soil $\mathrm{pH}$ in the Rice Field

Application of bio-fertilizer, basalt and GML in the acid sulfate soil increased soil $\mathrm{pH}$ from 3.8 to $>5.0$ and it remained at that level until crop harvest (Table 3). Significantly higher soil pH (5.27) was observed in the biofertilizer and GML treatments compared to that of the others. In basalt treatment, there was only a slight increase in soil $\mathrm{pH}(4.35)$ as basalt takes longer time to be completely disintegrated and reacted with the soils. 
Table 3. Effects of biofertilizer, ground magnesium limestone GML and basalt application on soil $\mathrm{pH}$.

\begin{tabular}{cccccc}
\hline & \multicolumn{5}{c}{ Soil $\mathbf{~ H H}$} \\
\cline { 2 - 6 } Treatments & $\mathbf{0}$ & $\mathbf{3 0}$ & $\mathbf{6 0}$ & $\mathbf{9 0}$ & $\mathbf{1 1 0}$ \\
\cline { 2 - 6 } & \multicolumn{7}{c}{ Days after Sowing } \\
\hline Control & $3.8 \mathrm{a}$ & $3.56 \mathrm{f}$ & $3.89 \mathrm{~d}$ & $3.95 \mathrm{~d}$ & $3.91 \mathrm{~d}$ \\
Biofertilizer & $3.8 \mathrm{a}$ & $4.11 \mathrm{~d}$ & $4.00 \mathrm{c}$ & $4.14 \mathrm{c}$ & $4.17 \mathrm{c}$ \\
a GML & $3.8 \mathrm{a}$ & $4.90 \mathrm{~b}$ & $4.39 \mathrm{a}$ & $4.53 \mathrm{~b}$ & $4.55 \mathrm{ab}$ \\
Basalt & $3.8 \mathrm{a}$ & $3.97 \mathrm{e}$ & $4.10 \mathrm{~b}$ & $4.46 \mathrm{~b}$ & $4.49 \mathrm{~b}$ \\
Biofertilizer + GML & $3.8 \mathrm{a}$ & $5.27 \mathrm{a}$ & $4.50 \mathrm{a}$ & $4.76 \mathrm{a}$ & $4.79 \mathrm{a}$ \\
Biofertilizer + Basalt & $3.8 \mathrm{a}$ & $4.35 \mathrm{c}$ & $4.20 \mathrm{~b}$ & $4.23 \mathrm{c}$ & $4.32 \mathrm{c}$ \\
\hline
\end{tabular}

Notes: Means within the same column followed by the same letters are not significantly different at $p<0.05$ $(n=4) ;{ }^{\text {a }}$ Ground magnesium limestone.

2.2.2. Effects of Biofertilizer, Basalt and Ground Magnesium Limestone (GML) Applications on the Growth of Rice and Yield

It was noted that aluminum severely affected the growth of rice and eventually its yield. The application of bio-fertilizer in combination with GML and basalt increased the yield of rice significantly. The highest grain yield of $6.82 \mathrm{t} \cdot \mathrm{ha}^{-1}$ was obtained for the bio-fertilizer in combination with GML treatment. This is consistent with the highest root length, tiller number, panicle length, fertile spikelets panicle ${ }^{-1}$, filled grains and weight of 1000 grains obtained in this treatment (Table 4).

Table 4. Effects of biofertilizer, ground magnesium limestone (GML) and basalt application on the growth and yield of rice.

\begin{tabular}{|c|c|c|c|c|c|c|c|c|c|}
\hline Treatments & $\begin{array}{c}\text { Root } \\
\text { Length } \\
\text { (cm) }\end{array}$ & $\begin{array}{c}\text { Tillers } \\
\text { plant }^{-1}\end{array}$ & $\begin{array}{c}\text { Number } \\
\text { of } \\
\text { Panicle } \\
\text { plant }^{-1}\end{array}$ & $\begin{array}{c}\text { Size of } \\
\text { Panicle }^{-1}\end{array}$ & $\begin{array}{c}\text { Fertile } \\
\text { Spikelets } \\
\text { panicle }^{-1}\end{array}$ & $\begin{array}{c}\text { Number of } \\
\text { Unfilled } \\
\text { Grains (\%) }\end{array}$ & $\begin{array}{l}\text { Weight } \\
\text { of } 1000 \\
\text { grain (g) }\end{array}$ & $\begin{array}{l}\text { Grain } \\
\text { Yield } \\
\mathbf{t} \cdot \mathbf{h a}^{-1}\end{array}$ & $\begin{array}{c}\text { Harvest } \\
\text { Index }\end{array}$ \\
\hline Control & $19.66 \mathrm{~d}$ & $9 \mathrm{c}$ & $7 \mathrm{c}$ & $17.83 \mathrm{e}$ & $61.01 \mathrm{e}$ & $26.21 \mathrm{a}$ & $17.02 \mathrm{~d}$ & $2.93 d$ & $0.40 \mathrm{e}$ \\
\hline Biofertilizer & $32.41 \mathrm{a}$ & $20 \mathrm{a}$ & $14 \mathrm{ab}$ & $20.10 \mathrm{c}$ & $119.51 b$ & $16.12 \mathrm{f}$ & $21.40 \mathrm{c}$ & $5.39 \mathrm{~b}$ & $0.35 \mathrm{~d}$ \\
\hline${ }^{\text {a }} \mathrm{GML}$ & $21.34 b$ & $19 a$ & $15 \mathrm{a}$ & $22.60 \mathrm{~b}$ & $116.81 \mathrm{~b}$ & $18.31 \mathrm{~d}$ & $22.33 b$ & $5.36 \mathrm{~b}$ & $0.45 b$ \\
\hline Basalt & $20.13 c$ & $16 b$ & $16 \mathrm{a}$ & $18.33 d$ & $98.85 d$ & $20.45 b$ & $20.01 \mathrm{c}$ & $3.47 \mathrm{c}$ & $0.41 \mathrm{c}$ \\
\hline $\begin{array}{c}\text { Biofertilizer } \\
+ \text { basalt }\end{array}$ & $22.30 \mathrm{~b}$ & $19 \mathrm{a}$ & $15 \mathrm{a}$ & $23.00 \mathrm{~b}$ & $107.32 \mathrm{c}$ & $19.24 \mathrm{c}$ & $23.68 \mathrm{a}$ & $5.33 c$ & $0.47 \mathrm{~b}$ \\
\hline $\begin{array}{c}\text { Biofertilizer } \\
\quad+\text { GML }\end{array}$ & $32.58 \mathrm{a}$ & $21 \mathrm{a}$ & $15 \mathrm{a}$ & $24.23 \mathrm{a}$ & $129.03 \mathrm{a}$ & $17.82 \mathrm{e}$ & $22.55 b$ & $6.82 \mathrm{a}$ & $0.55 \mathrm{a}$ \\
\hline
\end{tabular}

Notes: Means within the same column followed by the same letters are not significantly different at $p<0.05$ $(n=4) ;{ }^{a}$ Ground magnesium limestone.

\subsubsection{Effects of Application of Amendments on the Form of Aluminum in the Soil}

Application of amendments on the acid sulfate soil under study had significantly reduced the exchangeable form of Al. The highest exchangeable and weakly-bound Al was found in the control treatment (Table 5). Lower values of exchangeable and weakly-bound Al were found in the bio-fertilizer 
in combination with GML treatment compared to those of other treatments. However, the highest strongly-bound $\mathrm{Al}$ was found in the biofertilizer, while, the lowest was in the control treatment.

Table 5. Effects of bio-fertilizer, ground magnesium limestone (GML) and basalt application on the different forms of aluminum in soil after rice harvest.

\begin{tabular}{cccc}
\hline \multirow{2}{*}{ Amendments (4 t $\left.\cdot \mathbf{h a}^{\mathbf{- 1}} \mathbf{e a c h}\right)$} & Exchangeable Al & Weakly-bound Al & Strongly-bound Al \\
\cline { 2 - 4 } $\mathbf{c m o l}_{\mathbf{c}} \mathbf{~ g}^{-\mathbf{1}}$ \\
\hline Control & $2.09 \mathrm{a}$ & $3.04 \mathrm{a}$ & $4.78 \mathrm{f}$ \\
Biofertilizer & $0.11 \mathrm{~b}$ & $2.03 \mathrm{~b}$ & $11.69 \mathrm{a}$ \\
GML $^{\mathrm{a}}$ & $0.03 \mathrm{~d}$ & $1.13 \mathrm{f}$ & $7.23 \mathrm{~d}$ \\
Basalt & $0.07 \mathrm{c}$ & $1.65 \mathrm{c}$ & $9.02 \mathrm{~b}$ \\
Biofertilizer + GML & $0.01 \mathrm{e}$ & $1.34 \mathrm{e}$ & $6.34 \mathrm{e}$ \\
Biofertilizer + basalt & $0.04 \mathrm{~d}$ & $1.42 \mathrm{~d}$ & $8.53 \mathrm{c}$ \\
\hline
\end{tabular}

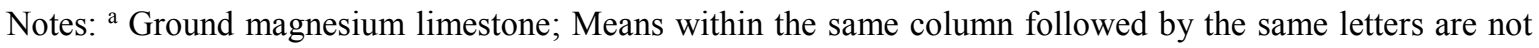
significantly different at $p<0.05(n=4)$.

\subsection{Discussion}

Highly exchangeable Al in acidic soil is a threat to rice growth and yield. In this study, we found that PGPB of the genus Bacillus, Stenotrophomonas and Burkholderia were capable of reducing the effects of Al toxicity. The main mechanism involved was the release of organic acids either by the rice roots or PGPB that chelated Al. Release of organic acids by plant roots can be considered as one of the ways that the plant defends itself against Al toxicity; this phenomenon is probably controlled by the genetic makeup of the rice plant. The reduction of Al toxicity was further enhanced by the presence of PGPB. It was proven that the bacteria were also able to produce not only organic acids, but also phytohormone and exopolysaccharides. The production of phytohormones (IAA) by PGPB has additional benefit for the plant growth and all PGPB were tested and found able to produce phytohormones from the earlier studies. Phytohormone enhanced root architecture that helps increase nutrient uptake from the surroundings. The common organic acids released by the rice roots and bacteria were oxalic, citric and malic acids. Organic acids are known as Al-chelating molecules. The low molecular weight organic acids secreted by plant root chelate $\mathrm{Al}$ in the soil solution, forming Al-citrate or Al-malate, preventing it from entering the root cells [15]. The most effective organic acid in alleviating toxic Al and Fe effects was citric, followed by oxalic and tartaric acids. Malic, malonic and salicylic acids were moderate in detoxifying $\mathrm{Al}$ and $\mathrm{Fe}[16]$.

Plants can detoxify $\mathrm{Al}$ in the rhizosphere by producing organic acids which can chelate $\mathrm{Al}$, rendering it unavailable to the growing crops. Citrate and malate are mostly present in the root tips. Under Al stress, rice root exuded organic acids that reduce the effects of Al toxicity by forming Al-citrate or Al-malate. It has been reported that among gramineous crops, rice demonstrates the highest level of Al-tolerance [17].

In the in vitro study, we found that high $\mathrm{Al}$ concentration severely affected the growth of rice seedlings during the planting period. Rice seedlings inoculated with the PGPB were less affected by the presence of high concentration of Al. The inoculated rice seedlings were shown to perform better compared to 
that of the non-inoculated seedlings, indicating that the bacteria were able to reduce the effects of $\mathrm{Al}$ toxicity via the mechanisms mentioned above.

It was observed in the present study that the PGPB was able to increase pH from 4.0-6.0. The isolates were able to produce polysaccharides that might absorb $\mathrm{H}^{+}$from the solution and increased $\mathrm{pH}$ in the rhizosphere zone. This is yet another mechanism that in reducing Al toxicity. At low $\mathrm{pH}(<5)$, $\mathrm{Al}$ dissolved, causing toxicity to the rice plants [18]. When the $\mathrm{pH}$ is increased to a value above 5.0 (the $\mathrm{pKa}$ of $\mathrm{Al}$ is 5), $\mathrm{Al}$ concentration in solution is reduced to a minimal level [19], and hence it is no longer a threat to the growth of rice. In the present study, the increase in $\mathrm{pH}$ occurred at the solution-rhizosphere interface. However, when $\mathrm{pH}$ was low $(<4.8)$, dissolved $\mathrm{Al}^{3+}$ in the soil solution can reach the critical level of $30 \mu \mathrm{M}$, which can damage rice plants. Aluminum toxicity is often related to phosphorus deficiency because a soil with high Al concentration will decrease the availability of $\mathrm{P}$ due to Al-Fe-phosphate interaction [20]. That is why the most recognized symptom of Al toxicity is P-related inhibition of root growth.

It was observed that bacterial population was slightly affected in the presence of high $\mathrm{Al}$ concentration. The microbial population was slightly reduced, most probably due to the increased inhibitory effects by releasing free $\mathrm{Al}$ [21], which is consistent with the previous findings [22,23]. The results of our study are in line with those mentioned above. It was proved that PGPB could survive in high Al concentration.

Rice can be grown satisfactorily when $\mathrm{Al}$ concentration is $<20 \mu \mathrm{M}$ [24]. Toxicity appears when there is a decrease in mitotic activity as a result of $\mathrm{Al}$ exposure to root tips of plants [25]. The inhibition of cell elongation could be the mechanism leading to root growth inhibition [26] as $\mathrm{Al}^{3+}$ is attracted to the negatively-charged cell walls of the roots [27]. SEM micrographs of the current study clearly showed the effects of high $\mathrm{Al}$ concentration on the root and leaf cells of rice where raptures of root cells and leaf glands were observed. But when the plants were inoculated with PGPB, these features were absent, showing the ameliorative contribution of the bacteria to rice plant.

Al toxicity causes severe changes to root morphology, resulting in curved, swollen, cracked, brownish, stubby and stiff root apices [28]. Al toxicity symptoms in plants are not easily identifiable unless their levels increase [29] which reduces the other nutrients' availability in the plant. The presence of high concentrations of $\mathrm{Al}$ can cause severe damage to the cells of rice roots [30]. The cells could break up and become disjointed, consequently affecting the growth of rice [31]. Liao et al. [32] found that non-tolerant Al plants were severely affected by exposure to Al. Aluminum disturbs the growth of cells in the elongation zone of roots [33]. Furthermore, Barker and Pilbeam [34] explained that Al can reduce root cell division; hence, it causes disruption of root cap processes, inhibiting root elongation. We believed that $\mathrm{Al}$ can affect rice roots in a similar fashion.

Several microorganisms such as Sphingomonas spp. are known to synthesize bacterial exopolysaccharides [35] and have been observed to perform a major role in providing protection to the cell as a boundary layer [36]. It is also able to chelate heavy metals due to the presence of several active functional groups [37].

The presence of high Al concentration severely affects the root morphology and the resulting decrease in root surface area simultaneously causes the $\mathrm{Ca}$ and $\mathrm{Mg}$ deficiencies [38]. Under this condition, GML application can alleviate the problem. The problem of Al toxicity can somewhat be alleviated by PGPB inoculation by which organic acids are secreted that chelate Al as well as production of phytohormones [12]. The results of the current study are consistent with the above findings. Rice plant 
has the mechanism to produce organic acids through root exudates, and it was observed in the current study that higher amounts of organic acids were released in the bacterial-inoculated treatments compared to that of the untreated rice seedlings.

In the field study, we found that the application of bio-fertilizer, GML and ground basalt positively affected the growth of rice due to reduction in Al toxicity. The reduction of $\mathrm{Al}$ in the soil by the application of GML increased soil $\mathrm{pH}$ and supplied sufficient $\mathrm{Ca}$ and $\mathrm{Mg}$ needed by rice growing in the field. The phosphate-solubilizing bacteria also increased bioavailable $\mathrm{P}$ to the plant as $\mathrm{P}$ is being fixed in the acidic soil. The presence of the bacteria in the bio-fertilizer helped secrete organic acids that chelated Al in the soil. Treating the acid sulfate soil with bio-fertilizer and GML, either alone or in combination, had alleviated its infertility that resulted in the increase of biomass and eventually rice yield.

It seems that the growth of rice roots was promoted by the bacteria present in the bio-fertilizer. These bacteria have the ability to promote the production of hormones such as indole-3-acetic acid [11] that enhanced plant growth $[39,40]$. Furthermore, bacterial inoculation ensured significant yield improvement by increasing $\mathrm{P}$ uptake, supplying $\mathrm{N}_{2}$ and phytohormone production.

The analysis of the soil showed significantly higher amounts of weakly-bound Al present in the control treatment, but in the bio-fertilizer or GML treatment, its amount was lowered significantly. This phenomenon had proven beyond doubt the possible chelation of the free Al in acid sulfate soils by the organic acids produced by the bacteria or a chemical reaction resulting from GML application. The presence of lower amounts of weakly-bound Al in the soil had promoted rice root development and increased surface area for higher nutrient uptake, leading to the increase in rice yield [41,42].

\section{Experimental Section}

\subsection{Experimental Site/Preparation and Conditions}

Laboratory experiments were conducted at Universiti Putra Malaysia, Serdang, while the field study on acid sulfate soil was conducted at Semerak, Kelantan, Malaysia. The main objective of laboratory study was to determine the mechanism of plant PGPB to alleviate Al toxicity and growth of rice. The PGBP isolates used were Bacillus sp. PSB16 Accession No: JX103827 (phosphate-solubilizing bacteria), Stenotrophomonas maltophila Sb16 Accession No: NR 041577.1 (Nitrogen fixing bacteria), Burkholderia thailandensisASB7 Accession No: NR 074312.1 (acid sulfate tolerant bacteria) and Burkholderia seminalis ASB21 Accession No: NR 042635.1 (acid sulfate tolerant bacteria). The ASB7 and ASB21 were isolated from the acid sulfate rice soils in Semerak, Malaysia, while the PSB16 and Sb16 were isolated from other rice fields in Malaysia. In the field study, the effect of PGPB present in bio-fertilizer, GML and ground basalt were studied. High yielding rice variety, MR219 was grown on an identified acid sulfate soil. Soil $\mathrm{pH}$, total $\mathrm{N}$, organic $\mathrm{C}$, available $\mathrm{P}$, exchangeable $\mathrm{K}$, exchangeable $\mathrm{Al}$, exchangeable $\mathrm{Ca}$ and exchangeable $\mathrm{Mg}$ was $3.80,0.12 \%, 2.10 \%, 19.20 \mathrm{mg} \cdot \mathrm{kg}^{-1}, 0.05,4.30,0.60$ and $0.70 \mathrm{cmol}_{\mathrm{c}} \mathrm{kg}^{-1}$, respectively. 


\subsection{Laboratory Study}

Rice seedlings (MR219) were inoculated with washed bacterial inoculums at approximately $5 \times 10^{9} \mathrm{CFU} \cdot \mathrm{mL}^{-1}$. Plant seedlings were grown for 21 days in growth chamber with $12 \mathrm{~h} \mathrm{light/dark}$ cycle at $29 \pm 1{ }^{\circ} \mathrm{C}$. The experiment was arranged in a completely randomized design (CRD) with four replications.

\subsubsection{Preparation of Inocula and Rice Seedlings Inoculation under in vitro Condition}

The bacterial strains were cultured in specific media plates for purity. The PSB were cultured in National Botanical Research Institute for Phosphorus agar NBRIP while $\mathrm{N}_{2}$ fixing bacteria were cultured in Jenson's broth for $72 \mathrm{~h}$. At the exponential growth stage, cells were harvested by centrifugation and washed with phosphate buffer solution. Approximately $5 \times 10^{9} \mathrm{~mL}^{-1}$ of live washed bacterial cells were used as inoculums in each bacterial treatment after transplanting. The population was confirmed by cell enumeration in drop plate method on NBRIP agar plate [43]. The rice seeds (MR219) were surface-sterilized [44]. The seeds were sown in a plastic tray lined with moist filter paper. Sterilized distilled water was added daily to moisten the seeds. Seedlings were grown for 7 days, after which three seedlings were transferred into Hoagland solution containing different concentrations of $\mathrm{Al}$ $(0,50$ and $100 \mu \mathrm{M})$ and grown for 21 days. The initial $\mathrm{pH}$ of the solution was adjusted to 4.0. Bacterial population, plant dry biomass, solution $\mathrm{pH}$, organic acids were determined. Root morphology was viewed under scanning electron microscope.

\subsubsection{Determination of Microbial Population at Different Al Concentrations}

One $\mathrm{mL}$ of broth was taken from Al treated sample at the initial and end of the study periods (21 days) for determination of bacterial growth. A series of 10 -fold dilution were prepared up to $10^{-10}$. The population of the bacteria was determined using drop plate count method on NBRIP media plate [43].

\subsubsection{Determination of Organic Acids and Indoleacetic Acid}

Organic acids were determined from plant growth medium at harvest using high performance liquid chromatography (HPLC) (Jasco Borwin software). Each sample from each treatment was injected into HPLC with a UV detector set at $210 \mathrm{~nm}$, using a Rezex ROA-organic acid $\mathrm{H}^{+}(8 \%)$ column $(250 \times 4.6 \mathrm{~mm})$ from Phenomenex Co. (Torrance, CA, USA); $0.005 \mathrm{~N} \mathrm{H}_{2} \mathrm{SO}_{4}$ was used as mobile phase with a flow rate of $0.17 \mathrm{~mL} \cdot \mathrm{min}^{-1}$. The amount of organic acids produced by the PGPB were estimated by deducting the organic acids present in the plant growth medium of control treatment from those present in the bacterial applied treated samples.

The PGPB were inoculated in broth with addition of tryptophan $\left(2 \mathrm{mg} \cdot \mathrm{L}^{-1}\right)$ and incubated at $28 \pm 2{ }^{\circ} \mathrm{C}$ for $48 \mathrm{~h}$. The culture was centrifuged at $7000 \mathrm{rpm}$ for $7 \mathrm{~min}$ and $1 \mathrm{~mL}$ of the supernatant was mixed with $2 \mathrm{~mL}$ of Salkowsky's reagent [45]. The indoleacetic acid (IAA) was determined using spectrophotometer at $535 \mathrm{~nm}$. 


\subsubsection{Determination of Root Morphology}

The morphology of the rice roots was studied by a root scanner (model Epson Expression 1680, equipped with root scanning analysis software). Total volume $\left(\mathrm{cm}^{3}\right)$ was quantified using the scanner [46]. The scanned roots data were processed by Win-Rhizo@ software (Reagent Instruments Inc., Québec, QC, Canada).

\subsubsection{Visual Observation of Plant Leaf and Root Cells}

Plant leaf and root cells of rice seedlings with bacterial colonization were observed under scanning electron microscope (SEM). The leaves and roots were cut into $1 \mathrm{~cm}$ and were pre-fixed with $4 \%$ glutaraldehyde overnight and washed with $0.1 \mathrm{M}$ sodium cacodylate buffer 3 times for 30 min each. Osmium tetraoxide buffer (1\%) was used for post fixation. After a series of dehydration in acetone (35\%, $50 \%, 75 \%, 95 \%$ and $100 \%$ ), the samples were dried in a critical point dryer and mounted on aluminum stubs, sputter-coated with gold and viewed under SEM (JEOL JSM-6400 attached with OXFORD INCA ENERGY 200 EDX).

\subsection{Field Study}

\subsubsection{Bio-Fertilizer, GML and Basalt Application and Transplanting}

The field study comprised six treatments: (i) Control [without any soil amendment]; (ii) bio-fertilizer at $4 \mathrm{t} \cdot \mathrm{ha}^{-1}$; (iii) GML $4 \mathrm{t} \cdot \mathrm{ha}^{-1}$; (iv) basalt $4 \mathrm{t} \cdot \mathrm{ha}^{-1}$; (v) bio-fertilizer + GML (4 $\mathrm{t} \cdot \mathrm{ha}^{-1}$ each); and (vi) bio-fertilizer + basalt $\left(4 \mathrm{t} \cdot \mathrm{ha}^{-1}\right.$ each). The bio-fertilizer is the consortium of four isolates Bacillus $\mathrm{sp}$. PSB16 Accession No: JX103827 (phosphate-solubilizing bacteria), Stenotrophomonas maltophilaSb16 Accession No: NR 041577.1 (nitrogen fixing bacteria), Burkholderia thailandensisASB7 Accession No: NR 074312.1 (acid sulfate tolerant bacteria) and Burkholderia seminalisASB21 Accession No: NR 042635.1 (acid sulfate tolerant bacteria) with the empty fresh bunch of oil palm and peat (1:1) contained $1.2 \% \mathrm{~N}, 0.12 \% \mathrm{P}, 0.65 \% \mathrm{~K}$, and $48 \% \mathrm{C}$. Approximately $5 \times 10^{9} \mathrm{~g}^{-1}$ of bacterial cells were used in the carrier material of biofertilizer. Twenty-one-day old rice seedlings (MR219) were transplanted on the research plots. The amendments (GML and ground basalt) were mixed thoroughly according to the treatments into the soil 15 days before transplanting. Nitrogen, phosphorus and potassium in the form of urea, rock phosphate and muriate of potash $(\mathrm{KCl})$ were applied at 120,30 and $60 \mathrm{~kg} \cdot \mathrm{ha}^{-1}$, respectively. Bio-fertilizer was formulated using the bacterial strains and was applied in the rice field planting and mixed thoroughly into the soil. Each plot size was $5 \times 5 \mathrm{~m}^{2}$ and was arranged in a Randomized Completely Block Design (RCBD) with four replications.

\subsubsection{Speciation of the $\mathrm{Al}$ in the Soils}

The Al forms in the soils were sequentially extracted by the following procedures: (i) exchangeable Al was extracted with $1 \mathrm{M} \mathrm{KCl}$ at 1:10 (soil/solution ratio) by shaking for $24 \mathrm{~h}$; (ii) weakly organically-bound $\mathrm{Al}$ form was extracted with $0.3 \mathrm{M} \mathrm{CuCl}_{2}$ at 1:10 (soil to solution ratio) by shaking for $2 \mathrm{~h}$; and (iii) total organically-bound $\mathrm{Al}$ form was extracted with $0.1 \mathrm{M} \mathrm{Na}_{4} \mathrm{P}_{2} \mathrm{O}_{7}$ at 1:10 (soil/solution ratio) by shaking for $24 \mathrm{~h}$. In all steps, the supernatant was separated by centrifugation for $20 \mathrm{~min}$ at $13,500 \mathrm{rpm}$. The quantity 
of strongly organically-bound $\mathrm{Al}$ was calculated as the difference between $\mathrm{Na}_{4} \mathrm{P}_{2} \mathrm{O}_{7}$ extracted-Al and $\mathrm{CuCl}_{2}$ extracted-Al [47]. The $\mathrm{Al}$ in the solution was analyzed using inductively coupled plasma atomic emission spectroscopy (ICP-AES).

\subsubsection{Rice Yield and Yield Contributing Characters}

Rice plant was harvested at grain maturity. At harvest, agronomic parameters (plant height, tiller number, root length) grain and straw yield were determined according to the procedure detailed [48].

\subsubsection{Statistical Analysis}

All data were statistically analyzed using the SAS Software Program (Version 9.3), and treatment means were separated by using Tukey's test $(p<0.05)$.

\section{Conclusions}

Aluminum toxicity is a common problem reducing the yield of rice grown in acid sulfate soils. This problem was alleviated by application of PGPB. The mechanism involved in the ameliorative process was chelation of free Al by the organic acids produced by the bacteria. These bacteria also increased soil $\mathrm{pH}$ that precipitated $\mathrm{Al}$ and produced phytohormone; both phenomena enhanced rice growth. Scanning electron micrographs of the roots and leaf tissues showed the clear ameliorative effects of PGPB inoculation. Furthermore, rice by itself was able to secrete organic acids via its roots when it was under the stress of high Al concentration. For the rice growing in the field, application of bio-fertilizer containing PGPB had increased yield due to the reasons mentioned above. Rice yield can also be increased further by applying GML or basalt at the appropriate rate. Low exchangeable and weakly-bound Al observed in the bio-fertilizer treatment were clear evidences for the chelation of Al by the organic acids. Hence, the PGPB under investigation can be used for the production of bio-fertilizer for rice cultivation in acid sulfate soils.

\section{Acknowledgments}

We wish to acknowledge Universiti Putra Malaysia and the Ministry of Education, Malaysia (the research was funded by LRGS - Food Security: Enhancing sustainable rice production, for financial and technical supports.

\section{Author Contributions}

QAP: experimentation and results discussion; UAN: support in characterization and results discussion; OR: support in results discussion; MRI: support in results discussion; JS: design and writing the paper and results discussion. All authors read and approved the final manuscript.

\section{Conflicts of Interest}

The authors declare no conflict of interest. 


\section{Abbreviations}

GML_-ground magnesium basalt; HPLC—high performance liquid chromatography; PGPB_Plant growth promoting bacteria; PSB — phosphate solubilizing bacteria; SEM—scanning electron microscope.

\section{References}

1. Marschner, H. Mechanisms of adaptation of plants to acid soil. Plant Soil. 1991, 134, 1-20.

2. Inostroza-Blancheteau, C.; Soto, B.; Ulloa, P.; Aquea, F. Resistance mechanisms of aluminum $\left(\mathrm{Al}^{3+}\right)$ phytotoxicity in cereals: Physiological, genetic and molecular bases. J. Soil Sci. Plant Nutr. 2008, 8, 57-71.

3. Ramgreeb, S.; Cook, J.A.; Watt, M.P. Responses of meristematic callus cells of two Cynodondactylon genotypes to aluminum. J. Plant Physiol. 2004, 161, 1245-1258.

4. Li, X.F.; Ma, J.F.; Matsumoto, H. Aluminum-induced secretion of both citrate and malate in rye. Plant Soil. 2002, 242, 235-243.

5. Mossor-Pietraszewska, T. Effect of aluminum on plant growth and metabolism. Acta Biochim. Pol. 2001, 3, 367-686.

6. Jones, D.L., Ryan, P.R., Eds. Nutrition. Aluminum toxicity. Encyclopedia of Applied Plant Science; Elsevier Science: London, UK, 2003; pp. 656-664.

7. Kochian, L.V. Cellular mechanisms of aluminum toxicity and resistance in plants. Annu. Rev. Plant Physiol. Plant Mol. Biol. 1995, 46, 237-260.

8. Zheng, S.; Ma, J.F.; Matsumoto, H. High aluminum resistance in buckwheat: I. Al-induced specific secretion of oxalic acid from root tips. Plant Physiol. 1998, 117, 745-751.

9. Yang, Z.M. Aluminum-induced cell wall peroxidase activity and lignin synthesis are differentially regulated by jasmonate and nitric oxide. J. Agric. Food Chem. 2008, 56, 9676-9684.

10. Ma, J.F.; Ryan, P.R.; Delhaize, E. Aluminum tolerance in plants and the complexing role of organic acids. Trends Plant Sci. 2001, 6, 273-278.

11. Naher, U.A.; Radziah, O.; Shamsuddin, Z.H.; Halimi, M.S.; Mohd Razi, I. Isolation of diazotrophs from different soils of Tanjong Karang rice growing area in Malaysia. Int. J. Agric. Biol. 2009, 11, 547-552.

12. Panhwar, Q.A.; Radziah, O.; Zaharah, A.R.; Shariah, M.; Mohd Razi, I. Isolation and characterization of phosphorus solubilizing bacteria from Aerobic rice. Afr. J. Biotechnol. 2012, 11, 2711-2719.

13. Nakkeeran, S.; Dilantha Fernando, W.G.; Siddiqui, Z.A. Plant growth promoting rhizobacteria formulations and its scope in commercialization for the management of pest and diseases. In PGPR: Biocontrol and Biofertilization; Siddiqui, Z.A., Ed.; Springer: Dordrecht, The Netherlands, 2005; pp. 257-296.

14. Ngoc Son, T.; Diep, C.N.; Giang, T.T.M. Effect of bradyrhizobia and phosphate solubilizing bacteria application on soybean in rotational system in the mekong delta. Omonrice 2006, 14, $48-57$. 
15. Pineros, M.A.; Kochian, L.V. Overview of the structure-function relations underlying functionality of ALMT and MATE-type transporters involved in the organic acid release Al tolerance response. In Proceedings of the 7th International Symposium on Plant-soil interactions at low $\mathrm{pH}$, Guangzhou, China, 17-21 May 2009; Liao, H., Yan, X., Kochian, L.V., Eds.; South China University of Technology Press: Guangzhou, China, 2009; pp. 55-56.

16. Yang, L.T.; Qi, Y.P.; Jiang, H.X.; Chen, L.S. Roles of organic acid anion secretion in aluminium tolerance of higher plants. Biomed. Res. Int. 2013, 2013, 173682.

17. Ma, J.F.; Shen, R.; Zhou, Z.; Misawa, M.; Takeuchi, Y. Response of rice to aluminum stress and identification of quantitative trait loci for aluminum tolerance. Plant Cell Physiol. 2002, 43, $652-659$.

18. Elisa Azura, A.; Shamshuddin, J.; Fauziah, C.I. Root elongation, root surface area and organic acid exudation by rice seedling under $\mathrm{Al}^{3+}$ and/or $\mathrm{H}^{+}$stress. Am. J. Agric. Biol. 2011, 6, 324-331.

19. Ismail, H.; Shamshuddin, J.; Syed Omar, S.R. Alleviation of soil acidity in ultisol and oxisol for corn growth. Plant Soil. 1993, 151, 55-65.

20. Ward, J.T.; Lahner, B.; Yakubova, E.; Salt, D.E.; Raghothama, K.G. The Effect of Iron on the Primary Root Elongation of Arabidopsis during Phosphate Deficiency. Plant Physiol. 2008, 147, 1181-1191.

21. Rousk, J.; Brookes, P.C.; Bååth, E. Contrasting soil pH effects on fungal and bacterial growth suggest functional redundancy in carbon mineralization. Appl. Environ. Microbiol. 2009, 75, 1589-1596.

22. Aciego Pietri, J.C.; Brookes, P.C. Relationships between soil pH and microbial properties in a UK arable soil. Soil Biol. Biochem. 2008, 40, 1856-1861.

23. Bååth, E. Growth rates of bacterial communities in soils at varying $\mathrm{pH}$ : a comparison of the thymidine and leucine incorporation techniques. Microb. Ecol. 1998, 36, 316-327.

24. Shamshuddin, J.; Elisa, A.A.; Shazana, M.A.R.S.; Fauziah, C.I.; Panhwar, Q.A.; Naher, U.A. Properties and management of acid sulphate soils in Southeast Asia for sustainable cultivation of rice, oil palm and cocoa. Adv. Agron. 2014, 124, 91-142.

25. Li, Y.; Yang, G.X.; Luo, L.T. Aluminum sensitivity and tolerance in model and elite wheat varieties. Cereal Res. Commun. 2008, 36, 257-267.

26. Zheng, S.J.; Yang, J.L. Target sites of aluminum phytotoxicity. Biol. Plant. 2005, 49, 321-331.

27. Yang, J.; Li, Y.; Zhang, Y.; Zheng, S. Possible involvement of cell wall pectic polysaccharides in Al resistance of some plant species. In Proceedings of the 7th International Symposium on Plant-Soil Interaction at Low pH, Guangzhou, China, 17-21 May 2009; Liao, H., Yan, X., Kochian, L., Eds.; South China University of Technology Press: Guangzhou, China, 2009; pp. 57-58.

28. Satish, A.B.; Damodar, V.P. Aluminum toxicity in plants-A review. J. Appl. Chem. 2013, 2, 447-474.

29. Foy, C.D. Tolerance of barley cultivars to an acid, aluminum-toxic subsoil related to mineral element concentrations in their shoots. J. Plant Nutr. 1996, 19, 1361-1380.

30. Farhana, J.A.; Shamshuddin, J.; Fauziah, C.I.; Husni, M.H.A. Effects of $\mathrm{Al}^{3+}, \mathrm{Fe}^{+3}$ and $\mathrm{H}^{+}$on root elongation and root surface area of rice seedling. In First National LRGS Rice Research Colloquium; UPM Press: Serdang, Malaysia, 2013; p. 45. 
31. Kopittke, P.M.; Blamey, F.P.C.; Menzies, N.W. Toxicities of soluble Al, Cu, and La include ruptures to rhizodermal and root cortical cells of cowpea. Plant Soil 2008, 303, 217-227.

32. Liao, H.; Wan, H.; Shaff, J.; Wang, X.; Yan, X.; Kochian, L.V. Phosphorus and Aluminum interaction in soybean in relation to $\mathrm{Al}$ tolerance. Exudation of specific organic acids from different region of the intact root system. Plant Physiol. 2006, 141, 674-684.

33. Bian, M.; Zhou, M.; Sun, D.; Li, C. Molecular approaches unravel the mechanism of acid soil tolerance in plants. Crop J. 2013, 1, 91-104.

34. Barker, A.V.; Pilbeam, D.J. Handbook of Plant Nutrition, 1st ed.; CRC/Taylor and Francis: London, UK, 2007; p. 613.

35. Sunil Pawar, T.; Amarsinh Bhosale, A.; Trishala Gawade, B.; TejswiniNale, R. Isolation, screening and optimization of exopolysaccharide producing bacterium from saline soil. J. Microbiol. Biotechnol. Res. 2013, 3, 24-31.

36. Caiola, M.G.; Billi, D.; Friedmann, E.I. Effect of desiccation on envelopes of the cyanobacterium Chroococcidiopsis sp. (Chroococcales). Eur. J. Physiol. 1996, 31, 97-105.

37. Kaplan, D.; Christiaen, D.; Arad, S.M. Chelating Properties of Extracellular Polysaccharides from Chlorella spp. Appl. Environ. Microbiol. 1987, 53, 953-2956.

38. Ridolfi, M.; Garrec, J.P. Consequences of the excess al and a deficiency in ca and mg for stomatal functioning and net carbon assimilation of beech leaves. Annu. Sci. 2000, 57, 209-218.

39. Bottini, R.; Cassán, F.; Piccoli, P. Gibberellin production by bacteria and its involvement in plant growth promotion and yield increase. Appl. Microbiol. Biotechnol. 2004, 65, 497-503.

40. Bloemberg, G.V.; Lugtenberg, B.J. Molecular basis of plant growth promotion and biocontrol by rhizobacteria. Curr. Opin. Plant Biol. 2011, 4, 343-350.

41. Panhwar, Q.A.; Shamshuddin, J.; Naher, U.A.; Radziah, O.; Mohd Razi, I. Biochemical and molecular characterization of potential phosphate-solubilizing bacteria in acid sulfate soils and their beneficial effects on rice growth. PLoS One 2014, 9, e97241.

42. Panhwar, Q.A.; Shamshuddin, J.; Naher, U.A.; Radziah, O.; Mohd Razi, I. Changes in the chemical properties of an acid sulfate soil and the growth of rice as affected by bio-fertilizer, ground magnesium limestone and basalt application. Pedosphere 2014, 24, 827-835.

43. Somasegaran, P.; Hoben, H.J. Methods in Legume-Rhizobium Technology; University of Hawaii NifTAL Project and MIRCEN, Department of Agronomy and Soil Science, Hawaii Institute of Tropical Agriculture and Human Resources, College of Tropical Agriculture and Human Resources, $1985 ;$ p. 365.

44. Amin, M.A.; Uddin, M.A.; Hossain, A. Regeneration study of some Indica rice cultivars followed by Agrobacterium-Mediated transformation of highly regenerable cultivar BR-8. J. Biol. Sci. 2004, 4, 207-211.

45. Gordon, A.S.; Weber, R.P. Colorometric estimation of indoleacetic acid. Plant Physiol. 1950, 26, 192-195.

46. Hamdy, E.L.Z.; Czarnes, S.; Hallett, P.D. Early changes in root characteristics of maize (Zea mays) following seed inoculation with the PGPR Azospirillum lipoferum CRT1. Plant Soil. 2007, 291, 109-118.

47. Drabek, O.; Boruvka, L.; Mladkova, L. Possible method of aluminum speciation in forest soil. J. Inorg. Biochem. 2003, 97, 8-15. 
48. Dobermann, A.; Fairhurst, T. Rice: Nutrient Disorders and Nutrient Management; International Rice Research Institute: Los Baños, Philippines, 2000; Volume 1, pp. 186-188.

Sample Availability: Samples of the compounds are not available from the authors.

(C) 2015 by the authors; licensee MDPI, Basel, Switzerland. This article is an open access article distributed under the terms and conditions of the Creative Commons Attribution license (http://creativecommons.org/licenses/by/4.0/). 